\title{
Pelatihan Pemasaran Online pada Mitra Lengis Nyuh di Tabanan
}

\author{
${ }^{1 *}$ I Putu Ramayasa, ${ }^{2}$ I Wayan Rupika Jimbara, ${ }^{3}$ I Wayan Kayun Suwastika, ${ }^{4}$ I Gede \\ Angga Candrawibawa \\ Institut Teknologi dan Bisnis STIKOM Bali ${ }^{1,2,3,4}$ \\ *Email: ramayasa@,stikom-bali.ac.id ${ }^{1}$, rupika@stikom-bali.ac.id ${ }^{2}$, kayun_suwastika@yahoo.com³
}

\begin{abstract}
Abstrak
UKM Lengis Nyuh merupakan salah satu UKM yang menjalankan usaha menjual minyak kelapa (lengis nyuh) yang dimiliki oleh Bapak I Wayan Doni Permana. Sebelum menjual minyak kelapa (lengis nyuh) mitra terlebih dahulu sudah menjalankan usaha sebagai pemasok kelapa muda selama 5 tahun. Sejak 1 tahun yang lalu mitra mengembangkan usahanya dengan menjual minyak kelapa (lengis nyuh) memanfaatkan buah kelapa tua dari hasil panen sebagai pemasok kelapa muda. Dalam menjalankan usahanya, mitra dibantu oleh adik sepupunya. Pemasaran dilakukan sederhana dari mulut kemulut serta melalui warung yang ada di sekitar tempat tinggal, sehingga pembelinyapun hanya dari warga sekitar. Selain itu, produk mitra belum memiliki label kemasan sehingga tampilannya kurang menarik. Akibatnya, pendapatan yang diperoleh belum sesuai harapan. Berdasarkan permasalahan yang dihadapi mitra, disepakati untuk membantu mitra melakukan pemasaran. Adapun metode yang digunakan pada kegiatan pengabdian ini yaitu sosialisasi, pelatihan dan evaluasi. Kegiatan pelatihan yang diberikan pada mitra adalah pemasaran melalui media sosial serta membuatkan label kemasan agar tampilan produk lebih menarik. Kegiatan evaluasi dari pelatihan yang dilakukan adalah melalui wawancara, tanya jawab dan pengamatan langsung yaitu ketrampilan mitra mengakses informasi yang tersedia di internet meningkat, mitra mengalami peningkatan dalam menggunakan email dan mitra mampu melakukan pemasaran online secara mandiri dengan memposting produknya di Facebook dan Instagram.
\end{abstract}

Kata kunci : Pelatihan, Pemasaran Online, Minyak Kelapa

\begin{abstract}
Small amd medium-sized enterprise (SME) of Lengis Nyuh is one of SME which sells coconut oil (lengis nyuh) which is owned by Mr. I Wayan Doni Permana, the partner. Before he sells coconut oil, he already is involved in supplying young coconuts for five years. Since one year ago, he developed his entrepreneur by selling coconut oil (lengis nyuh) by utilizing the old coconuts to that he got from the young coconuts harvest. In managing his business, he was helped by his younger cousin. Because of that simple marketing strategy, through mouth to mouth, and also through the little shops around the neighborhood, thus the buyers were only surrounding people there. Besides that, the packaging used to sell the products did not have any labels, which makes them unattractive. This results in the income to that they received was not sufficient. From the problem that faced by partners be negotiated to helped partners
\end{abstract}


do marketing. The method that used in this service activities are socialisation, training, and evaluation. This training activities provided to the partners is marketing through social media and also making packaging labels to make product looks more attractive. Evaluation activities of training are through interviews, question and answer and direct observation, namely the skills of partners accessing information available on the internet increased, partners experienced an increase in using email and partners were able to do online marketing independently by posting their products on Facebook and Instagram.

Key words: Training, Online Marketing, Coconut Oil

\section{PENDAHULUAN}

Indonesia merupakan negara dengan garis pantai terpanjang ketiga di dunia. Salah satu tanaman yang banyak tumbuh ditepi pantai adalah pohon kelapa. Sehingga tidak mengherankan Indonesia termasuk penghasil kelapa paling banyak di dunia. Pohon yang bisa tumbuh hingga setinggi 30 meter ini disebut sebagai tanaman paling serbaguna. Sejak lama kelapa sudah diolah serta dimanfaatkan mulai dari pucuk sampai akarnya.

Bali sebagai daerah yang termasuk kategori tropis membuat pohon kelapa tumbuh dengan suburnya. Di Bali yang mayoritas penduduknya beragama Hindu, kelapa mempunyai peranan yang sangat penting khususnya untuk kebutuhan sarana upacara keagamaan. Sehingga tidak mengherankan apabila kelapa di Bali memiliki nilai ekonomis yang tinggi. Produk pohon kelapa mulai dari daun (muda dan tua), bunga, buah (muda dan tua), serta batangnya semua dimanfaatkan oleh masyarakat umat Hindu yang ada di Bali (Januhari \& Puwantara, 2018). Salah satu UKM yang memanfaatkan buah kelapa sebagai produknya adalah UKM Lengis Nyuh yang dimiliki oleh Bapak I Wayan Doni Permana. UKM ini berlokasi di Banjar Cau, Desa Tua, Kecamatan Marga, Kabupaten Tabanan. Sebelum menjalankan usaha menjual lengis nyuh, atau minyak kelapa mitra terlebih dahulu sudah menjalankan usaha sebagai pemasok kelapa muda selama 5 tahun, yang dipasarkan di sekitar daerah Tabanan. Sebagai pemasok mitra mendapatkan buah kelapa muda dari kebun warga yang ada di sekitar wilayah kecamatan Marga Tabanan. Sebagai pemasok kelapa muda tidak jarang dalam proses panen mitra juga mendapatkan buah kelapa yang tua. Hal ini terjadi karena sistem memanen yang dilakukan perpohon bukan per buah. Jadi tidak semua kelapa muda yang dipetik, tetapi buah kelapa yang sudah tua juga. Hal ini mengakibatkan mitra saat panen terkadang mengalami kerugian karena jumlah buah kelapa muda yang di dapat tidak banyak, sedangkan sebagian merupakan buah kelapa yang sudah tua. Sejak 1 tahun yang lalu mitra mencoba untuk mengembangkan usahanya dengan mengolah buah kelapa tua menjadi minyak kelapa (lengis nyuh) atau orang Bali sering juga menyebutnya dengan sebutan lengis tandusan atau lengis melah. 


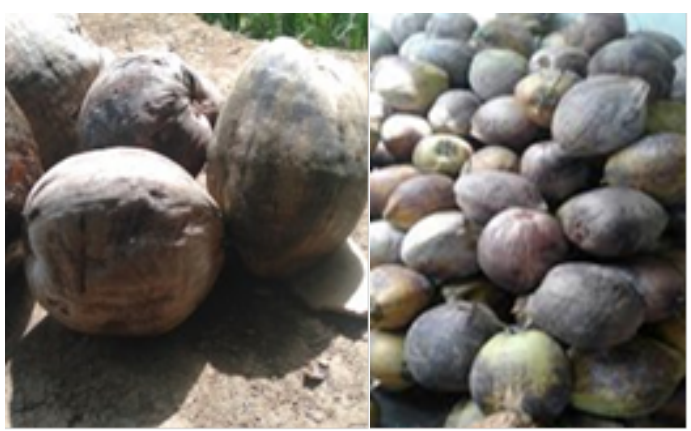

Gambar 1. Buah Kelapa Mitra

Dalam menjalankan usahanya ini mitra dibantu oleh adik sepupunya. Dari mencoba mengolah buah kelapa tua menjadi minyak kelapa (lengis nyuh) ini, mitra berharap bisa mendapatkan keuntungan, sehingga pendapatannya tidak hanya bergantung dari sebagai pemasok kelapa muda saja, tapi juga dari hasil menjual minyak kelapa (lengis nyuh). Namun karena pemasaran yang masih sederhana hanya dari mulut kemulut serta melalui warung-warung yang ada di sekitar tempat tinggal mitra. Maka pembelinyapun hanya dari warga sekitar. Selain itu kemasan yang digunakan juga tidak memiliki label sehingga tampilan kurang menarik dan higienis. Akibatnya pendapatan yang diperoleh dari usaha menjual minyak kelapa ini belum bisa sesuai harapan. Hal ini pula yang menyababkan mitra belum berani memproduksi minyak kelapa setiap hari tetapi 3 atau 4 hari sekali.

Pada saat tim pengabdian pertama kali melakukan kunjungan ke lokasi serta mewawancarai mitra, diperoleh informasi bahwa hasil yang diperoleh dari penjualan minyak kelapa hanya sekitar Rp.300.000 sampai dengan 400.000 per bulan, dengan harga jual 20.000 per botol. Jika dibandingkan dengan UKM lain yang memiliki jenis usaha yang sama dengan mitra, hasil penjualan ini tergolong sedikit. Padahal minyak kelapa memiliki banyak manfaat dan nilai ekonomis yang menjanjikan jika dikelola dengan baik. Berdasarkan hasil diskusi, tim pengabdian telah mengidentifikasi permasalahan yang dihadapi mitra. Mitra mengalami masalah di bidang pemasaran yang masih dilakukan secara sederhana. Kurangnya pemahaman mitra tentang pemanfaatkan teknologi informasi dalam melakukan pemasaran secara online dengan memanfaatkan kecanggihan media sosial menjadi faktor produk mitra belum dikenal luas. Media sosial dapat memudahkan semua orang untuk dapat berkomunikasi, berpartisipasi, saling berbagi dan membentuk sebuah jaringan secara online, sehingga dapat menyebarluaskan konten mereka sendiri (Viny 2016). Selain itu, kemasan yang tanpa label juga membuat tampilan produk mitra kurang menarik. Padahal label kemasan mempunyai manfaat yang sangat penting untuk dapat disertakan pada kemasan produk (Hendrasty 2013). Adanya pelabelan pada kemasan dapat meningkatkan nilai penjualan (Rosandi \& Sudarwanto 2014). Memperhatikan permasalahan yang dihadapi oleh mitra, tim pengabdian sepakat untuk membantu mitra melakukan pemasaran dengan cara memberikan pelatihan dengan media sosial untuk melakukan pemasaran dan membuatkan label kemasan agar tampilan produk keliatan lebih menarik dan higienis. Pelatihan pemasaran secara online bertujuan untuk membuatkan kemasan yang lebih menarik sehingga bisa memberikan keuntungan bagi mitra baik dalam hal pemasaran maupun pendapatan. 


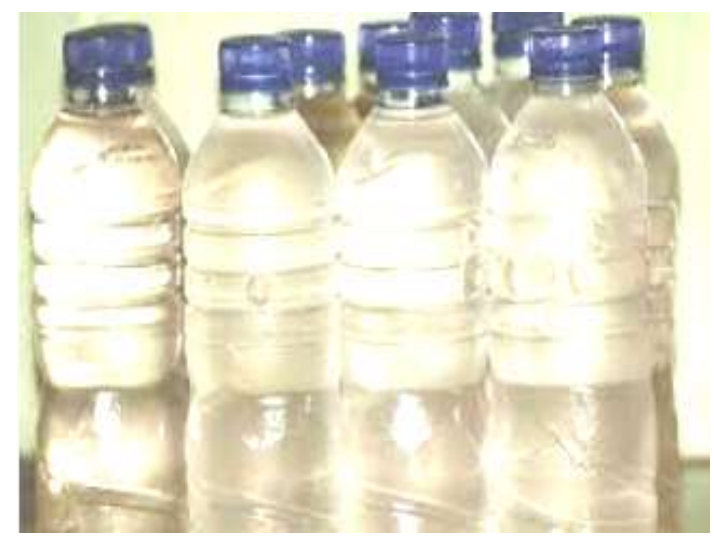

Gambar 2 Minyak Kelapa (lengis nyuh)

\section{RUMUSAN MASALAH}

Berdasarkan dari hasil analisis terhadap situasi dan masalah yang dihadapi oleh mitra, maka permasalahan prioritas yang dicarikan solusi dalam kegiatan pengabdian masyarakat ini adalah bagaimana teknik pemasaran yang lebih professional dan efektif yaitu pemasaran secara online, serta pembuatan label kemasan produk yang mampu menunjukkan ciri khas serta memberikan ketertarikan pada konsumen.

\section{METODE}

Berdasarkan permasalahan prioritas yang ditangani, maka metode yang akan dilakukan pada pengabdian masyarakat ini adalah membantu memasarkan produk mitra dengan memberikan pelatihan pemasaran secara online dengan memanfaatkan media sosial seperti Facebook dan Instagram. Facebook dan Instagram menjadi pilihan media sosial yang menarik karena banyak orang dapat terhubung dengan mudah serta dapat dengan mudah juga membagikan segala produk dan usaha yang ingin dipublikasi oleh pelaku usaha ( Nanik, Novianti \& Sedana, 2019). Selanjutnya mitra dibuatkan desain label dan label yang sudah dicetak agar dapat langsung ditempel pada kemasan botol plastik yang digunakan untuk tempat minyak kelapa (lengis nyuh). Selanjutnya dilaksanakan Evaluasi setelah semua proses kegiatan dilakukan. Berikut ini merupakan alur prosedur kerja dari kegiatan pengabdian masyarakat bisa di lihat pada Gambar 3 .

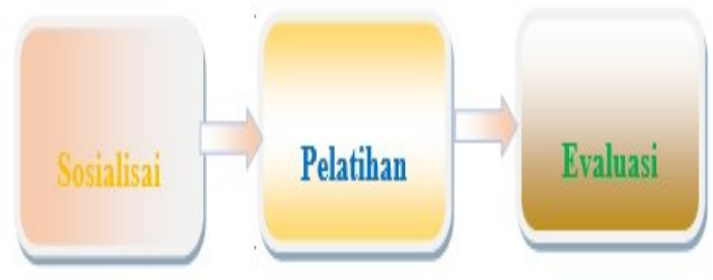

Gambar 3. Prosedur Kerja

\section{PEMBAHASAN}

Kegiatan pengabdian masyarakat ini terdiri dari tiga tahap dengan tujuan membantu mitra melakukan pemasaran produk melaui media sosial. Kegiatan Pengabdian ini dilaksanakan di lokasi UKM mitra yaitu di Banjar Cau, Desa Tua, Kecamatan Marga, kabupaten Tabanan. Seperti tampak pada peta Gambar 4.

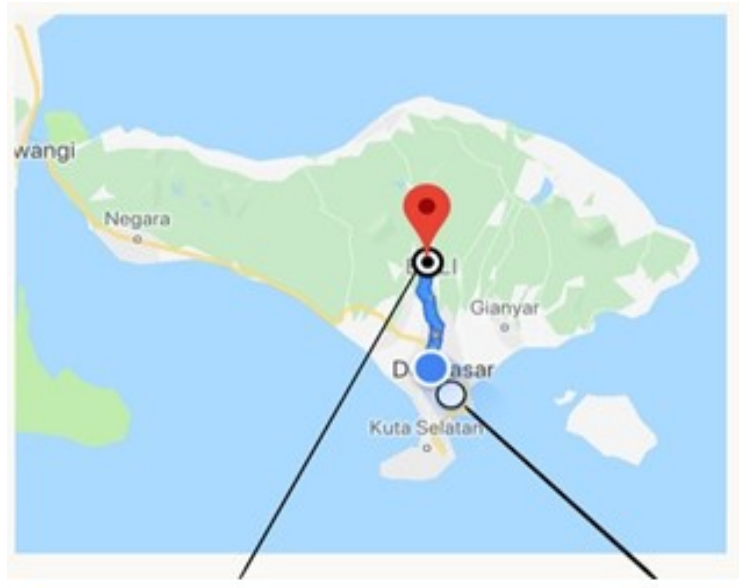

Lokasi Pengabdian

ITB STIKOM BALI

Gambar 4. Lokasi Pengabdian Masyarakat

Adapun Susunan kegiatan yang dilakukan pada kegiatan pengabdian 
masyarakat ini dapat dilihat pada Tabel 1 berikut ini.

Tabel 1. Susunan Acara Kegiatan

\begin{tabular}{|c|l|c|}
\hline No & \multicolumn{1}{|c|}{ Acara } & Durasi \\
\hline 1 & Sosialisasi & Jam \\
\hline 2 & Pelatihan & 4 Jam \\
\hline 3 & $\begin{array}{l}\text { Pemberian Label } \\
\text { Kemasan dan Evaluasi }\end{array}$ & 2 Jam \\
\hline
\end{tabular}

Berikut ini merupakan uraian pelaksanaan kegiatan berdasarkan susunan acara yang telah dibuat.

(1) Sosialisasi

Kegiatan sosialisasi pada pengabdian masyarakat ini dilaksakan di rumah mitra. Pada kegiatan sosialisasi ini disampaikan beberapa informasi yang meliputi latar belakang, target, sasaran dan tujuan dari kegiatan pengabdian ini. Pada kegiatan sosialisi ini juga di bahas tentang jumlah peserta yang mengikuti kegiatan pelatihan, serta peralatan apa saja yang digunakan saat pelatihan, tempat pelatihan serta mekanisme pelatihan. Gambar 5 menunjukan sedang dilaksanakannya sosialisasi pengabdian.

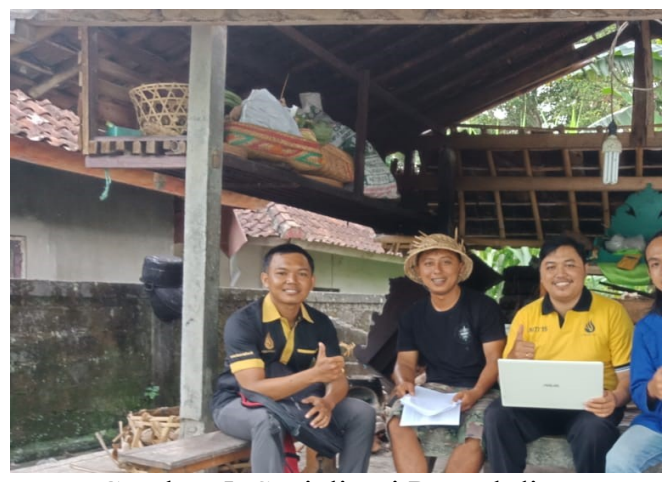

Gambar 5. Sosialisasi Pengabdian
(2) Pelatihan

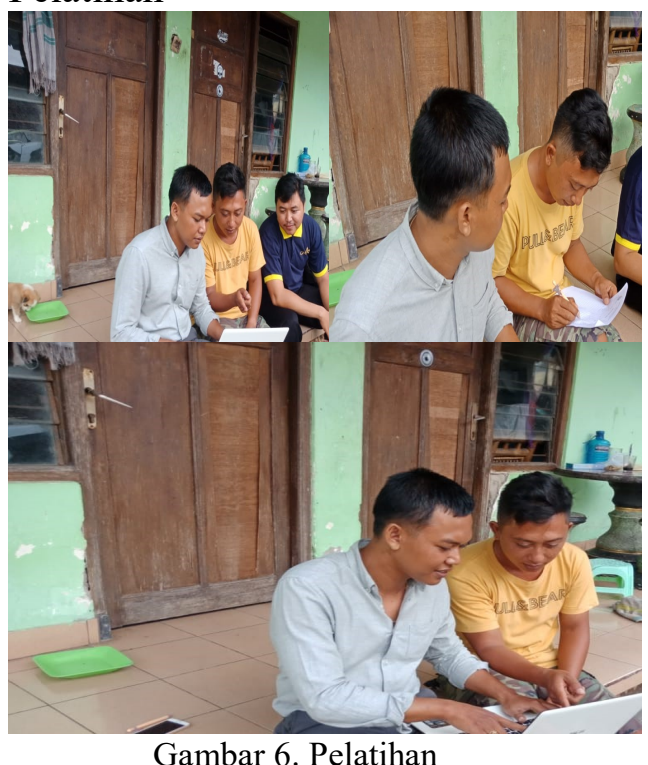

Kegiatan pelatihan diberikan oleh tim pengabdian. Adapun materi pelatihan yang diberikan oleh tim pengabdian yaitu :

a. Pengenalan Internet

Sebelum dijelaskan tentang pemasaran dengan media sosial, mitra terlebih dahulu dijelaskan secara ringkas tentang pengenalan internet yang meliputi sejarah awal kemunculan internet, cara kerja internet, serta dijelaskan manfaat dan kelebihan yang bisa diperoleh dari internet. Pengenalan ini penting karena pemahaman mitra yang masih kurang tentang pemanfaatan internet untuk melakukan pemasaran secara online.

b. Pengenalan Browser

Pada pengenalan browser ini dijelaskan mengenai manfaat dari browser, jenis-jenis browser, serta dijelaskan mengenai fungsi tombol menu bar yang ada pada browser. Hal ini dianggap sangat penting karena untuk bisa mengakses halaman web diperlukan sebuah browser. Browser 
yang digunakan pada pelatihan ini adalah Mozila Firefox. Gambar Browser bisa dilihat pada Gambar 7.

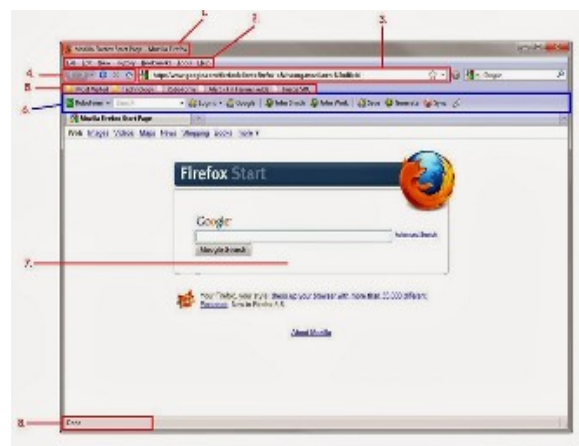

Gambar 7. Mozila Firefox

c. Search Engine

Search Engine merupakan sebuah program komputer yang khusus difungsikan untuk membantu pengguna dalam mencari berkasberkas yang tersimpan dalam layanan World Wide Web atau news group pada sejumlah jaringan komputer server. Search engine yang digunakan pada kegiatan pelatihan ini adalah www.Google.com. Pada sesi ini Mitra dijelaskan tentang cara menggunakan search engine, serta diberikan tips dan trik cara mencari informasi dengan Google. Dalam Pelatihan pengabdian masyarakat ini mitra dijelaskan dengan melakukan praktek secara langsung dengan laptop yang sudah disediakan oleh Tim Pengabdian. Berikut ini merupakan tampilan search engine Google. $\prod_{\text {Google }}$

$\leftrightarrow x$ Q A htpss//www.google.com/gows_rd=ssl
Gambar 8. Search Enggine Google

\section{d. Email}

Email atau surat elektronik adalah suatu sarana untuk mengirim dan menerima surat atau pesan dengan format digital melalui jalur jaringan komputer dan internet. Saat ini, mengirim pesan dengan email merupakan salah satu cara yang paling efisien, cepat, dan murah, sehingga sangat penting bagi mitra dijelaskan tentang email terutama untuk berkomunikasi dengan calon pembeli. Selain itu, akun email juga diperlukan untuk daftar menggunakan media sosial (Wong J. 2010), sehingga pada materi email ini mitra dijelaskan secara ringkas mengenai definisi email, manfaat email, jenis-jenis email serta cara kerja email. Untuk kegiatan pelatihannya mitra diajak secara langsung membuat email baru yang nantinya akan digunakan untuk mendaftar di media sosial. Berikut ini merupakan halaman email mitra pada Gambar 9. 


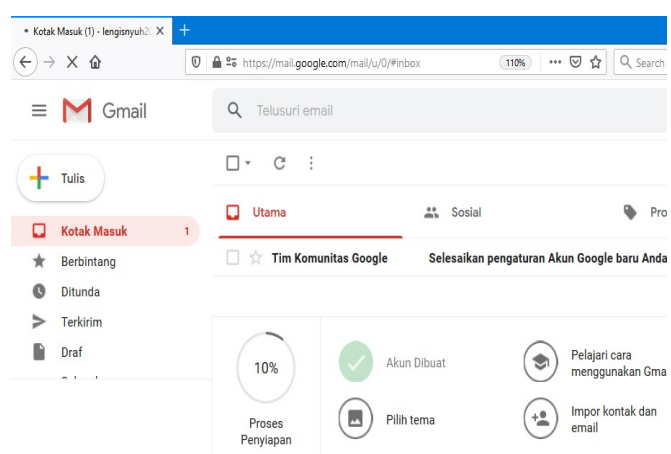

Gambar 9. Email Mitra

e. Pelatihan Pemasaran Produk dengan Facebook

Facebook merupakan salah satu media sosial yang banyak digunakan oleh masyarakat sebagai sarana pergaulan sosial secara online (As'ad, H. AbuRumman. 2014). Di Facebook pengguna dapat berkomunikasi, berinteraksi, berbagi, networking dan melakukan berbagai kegiatan lainnya (Puntoadi \& Danis 2011). Pada pelatihan ini mitra dijelaskan tentang cara membuat Facebook dengan menggunakan email yang sebelumnya sudah dibuat oleh mitra, serta cara memanfaatkan Facebook untuk memasarkan produk. Pada halaman Facebook mitra dapat memasarkan produk yang dihasilkannya, sehingga bisa dikenal lebih luas. Berikut ini merupakan tampilan Facebook dari mitra, bisa dilihat pada Gambar 10 .

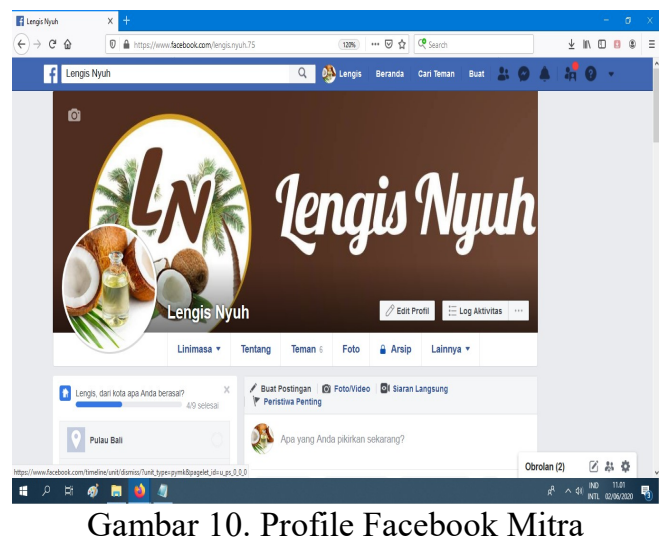

f. Pelatihan Pemasaran Produk dengan Instagram

Instagram adalah sebuah aplikasi berbagi foto dan mengambil gambar atau foto yang menerapkan filter digital untuk mengubah tampilan efek foto, dan membagikannya ke berbagai layanan media sosial, termasuk milik Instagram sendiri. Semakin banyak orang yang menyadari bahwa Instagram merupakan salah satu alat promosi yang sangat ampuh (Nisrina 2015 ). Kecenderungan para pengguna internet ialah lebih tertarik pada bahasa visual. Dibandingkan dengan media sosial lainnya, Instagram lebih memaksimalkan fiturnya untuk komunikasi melalui gambar atau foto. Ketika bahasa visual mendominasi dunia internet, dari situlah para pelaku usaha bisa memanfaatkan peluang yang terhampar di depan mata. Pada pelatihan ini mitra dijelaskan cara membuat Instagram. Mitra dapat membuat konten yang menarik untuk memasarkan produknya dengan memanfaatkan akun Instagram. Kombinasi strategi pemasaran yang tepat serta konten yang menarik dapat memasarkan produk mitra dengan jangkauan konsumen yang lebih luas. 
Gambar 11 adalah tampilan Instagram mitra.

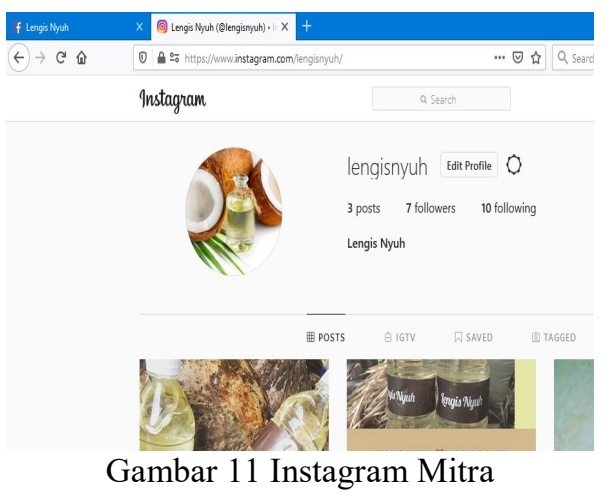

g. Pemberian Kemasan dan Label

Pemberian kemasan serta label ini bertujuan agar kemasan keliatan lebih menarik. Perancangan pembuatan label dilakukan dengan menggunakan teori desain kemasan (Anwari et al. 2018). Pada label berisi nama produk atau merek, serta berisi alamat Facebook serta Instagram dari produk yang dapat memudahkan konsumen untuk bisa melakukan pemesanan. Adanya label pada kemasan produk dapat meningkatkan pemasaran dan pendapatan mitra. Gambar 12 dan 13 merupakan tampilan label dan kemasan yang dibuat untuk mitra.

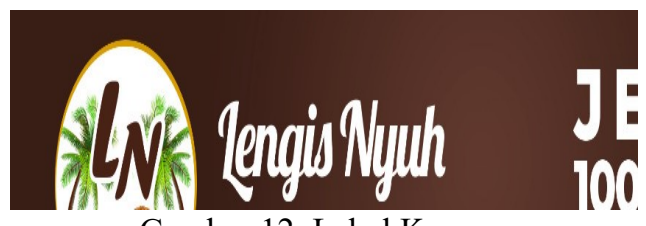

Gambar 12. Label Kemasan
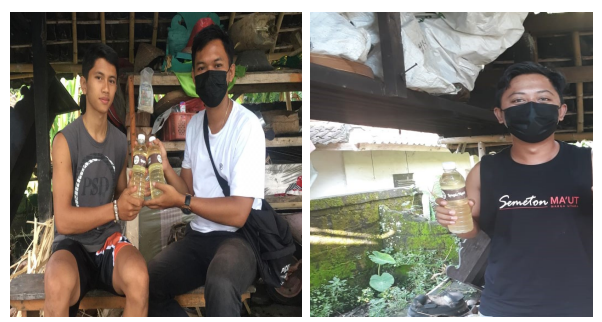

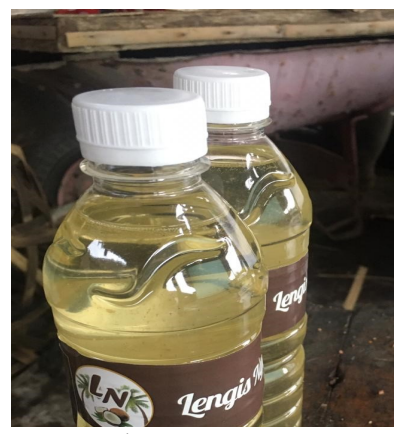

Gambar 13 Kemasan

(3) Evaluasi

Evaluasi ini dilakukan untuk mengetahui kemampuan mitra setelah mengikuti pelatihan dan mengetahui manfaat yang dirasakan setelah pelatihan. Evaluasi ini dilakukan selama 1 jam. Kegiatan pelatihan yang diberikan ini mendapatkan respon yang positif dari mitra. Ini terlihat dari antusiasnya mitra saat mengikuti pelatihan yang diberikan. Berdasarkan wawancara, tanya jawab serta pengamatan langsung selama kegiatan dilakukan, kegiatan pengabdian masyarakat ini memberikan hasil evaluasi yaitu:

1. Ketrampilan mitra menggunakan serta mengakses informasi yang tersedia di internet meningkat.

2. Pemahaman serta keterampilan mitra mengalami peningkatan dalam menggunakan email, serta media sosial, untuk melakukan pemasaran secara online.

3. Mitra sudah mampu melakukan pemasaran online secara mandiri dengan memposting produknya di Facebook dan Instagram.

Selain itu evaluasi juga dilakukan dengan memberikan kuisioner kepada mitra mengenai pelatihan yang diberikan dengan menggunakan skala likert.

Rumus index $\%=$ Total Skor $/ \mathrm{Y}$ x 100. 
Berikut ini merupakan hasil kuisioner yang diberikan kepada mitra, bisa dilihat pada tabel 2 .

Tabel 2. Hasil Kuisioner

\begin{tabular}{|c|c|c|}
\hline No & Pernyataan & Index \\
\hline 1 & $\begin{array}{l}\text { Bagaimana menurut anda } \\
\text { mengenai kegiatan } \\
\text { Pengabdian Masyarakat } \\
\text { untuk IRT Mitra Lengis } \\
\text { Nyuh? }\end{array}$ & $100 \%$ \\
\hline 2 & $\begin{array}{l}\text { Bagaimana menurut anda } \\
\text { rencana kegiatan } \\
\text { sosialisasi pengabdian } \\
\text { masyarakat yang } \\
\text { dipaparkan sebelum } \\
\text { kegiatan pelatihan } \\
\text { dilaksanakan? }\end{array}$ & $100 \%$ \\
\hline 3 & $\begin{array}{l}\text { Apakah menurut anda } \\
\text { pemaparan materi oleh } \\
\text { narasumber pada Kegiatan } \\
\text { Pengabdian Masyarakat }\end{array}$ & $75 \%$ \\
\hline 4 & $\begin{array}{l}\text { Apakah menurut anda } \\
\text { materi yang diberikan oleh } \\
\text { narasumber bermanfaat? }\end{array}$ & $100 \%$ \\
\hline 5 & $\begin{array}{l}\text { Bagaimana menurut anda } \\
\text { pemasaran dengan } \\
\text { Facebook dan Instagram, } \\
\text { yang digunakan } \\
\text { narasumber sebagai materi } \\
\text { pemasaran? }\end{array}$ & $100 \%$ \\
\hline 6 & $\begin{array}{l}\text { Bagaimana menurut anda } \\
\text { penyajian materi serta } \\
\text { pelatihan media pemasaran } \\
\text { yang digunakan oleh } \\
\text { narasumber? }\end{array}$ & $100 \%$ \\
\hline 7 & $\begin{array}{l}\text { Apakah anda memahami } \\
\text { materi media pemasaran } \\
\text { yang diberikan oleh } \\
\text { narasumber pada kegiatan } \\
\text { Pengabdian Masyarakat }\end{array}$ & $75 \%$ \\
\hline
\end{tabular}

\begin{tabular}{|c|l|l|}
\hline & ini? & \\
\hline 8 & $\begin{array}{l}\text { Apakah kegiatan } \\
\text { Pengabdian Masyarakat ini } \\
\text { membantu anda } \\
\text { mengembangkan media } \\
\text { pemasaran seperti } \\
\text { Facebook dan Instagram, } \\
\text { dalam materi yang } \\
\text { diberikan untuk } \\
\text { meningkatkan hasil } \\
\text { penjualan produk? }\end{array}$ & \\
\hline 9 & $\begin{array}{l}\text { Apakah pelaksanaan } \\
\text { Pengabdian Masyarakat ini } \\
\text { membantu anda } \\
\text { memperkenalkan produk } \\
\text { anda kepada masyarakat? }\end{array}$ & \\
\hline 10 & $\begin{array}{l}\text { Apakah pelaksanaan } \\
\text { Program Pengabdian } \\
\text { kepada Masyarakat ini } \\
\text { dapat membantu anda } \\
\text { memperluas jangakauan } \\
\text { pemasaran produk yang } \\
\text { anda jalankan? }\end{array}$ & \\
\hline Rata-rata index(\%) & $100 \%$ \\
\hline
\end{tabular}

Perhitungan interval kategori dapat dihitung yaitu:

$\mathrm{I}=100 / 4=25$

Kategori :

$0-24,9 \%=$ Kurang

$25-44,9 \%=$ Cukup

$45-74,9 \%=$ Baik

$75-100 \%=$ Sangat Baik

Dari hasil kuisioner dengan menghitung Index \% evaluasi kegiatan Pengabdian Masyarakat diperoleh hasil 92,5\% yang termasuk dalam kategori sangat baik.

\section{SIMPULAN}

Berdasarkan kegiatan pengabdian masyarakat yang sudah dijalankan maka 
dari hasil evaluasi dapat diambil kesimpulan sebagai berikut :

1. Kegiatan pelatihan pada pengabdian masyarakat ini mendapat respon yang positif dari mitra. Pada saat pelatihan mitra sangat antusias mengikuti arahan pelatihan yang diberikan.

2. Kegiatan pelatihan ini meningkatkan ketrampilan mitra dalam mencari informasi melalui Google serta dalam menggunakan email untuk media komunikasi.

3. Mitra sudah mampu melakukan pemasaran online melalui media sosial Facebook dan Instagram secara mandiri.

4. Dengan diberikan label pada kemasan produk mitra mudah dikenali, serta memudahkan konsumen untuk dapat melakukan pemesanan karena pada label terdapat alamat Facebook serta Instagram dari produk mitra.

\section{UCAPAN TERIMA KASIH}

Kami menyadari tanpa bantuan dari berbagai pihak kegatan pengabdian masyarakat ini tidak akan bisa selesai dengan baik. Untuk itu kami mengucapkan terima kasih kepada Institut Teknologi dan Bisnis STIKOM Bali atas dukungan dan dana pengabdian yang sudah diberikan kepada tim pengabdian, sehingga segala kegiatan pengabdian masyarakat yang dijalankan bisa berjalan dengan baik dan lancar. Selanjutnya kami juga mengucapkan terima kasih kepada Ka.LPPM ITB STIKOM Bali yang sudah memfasilitasi hingga terselesaikannya pengabdian masyarakat ini. Tidak lupa kami juga mengucapkan terima kasih Kepada Bapak Wayan Doni Permana selaku mitra yang sudah menyambut kami dengan baik selama proses kegiatan pengabdian masyarakat berlangsung. Semoga kegiatan yang kami berikan bisa memberikan manfaat untuk kemajuan UKM mitra.

\section{DAFTAR PUSTAKA}

Januhari, Ni Nyoman Utami, Purwantara, I Made Adi. 2018. 'Pelatihan Penggunaan Internet Sebagai Media Pemasaran Online Pada KWT VCO Tabanan' WIDYABHAKTI JURNAL ILMIAH POPULER V.1(1): November.

Viny Putri Fauzi, 2016 Pemanfaatan Instagram Sebagai Sosial media Marketing Er-corner Boutiquen Dalam Membangun Brand Awareness di Kota Pekanbaru, JOM FISIP Vol. 3 No. 1, hal 1-15.

Hendrasty, H.K., 2013. Pengemasan \& Penyimpanan Bahan Pangan1st ed., Yogyakarta: Graha Ilmu.

Rosandi, S. \& Sudarwanto, T., 2014. Pengaruh Citra Merek dan Desain Kemasan Terhadap Minat Beli Konsumen pada Produk Susu Ultra. Jurnal Pendidikan Tata Niaga, 2(2), pp.1-16, Juli.

Hendayanti N P N, Novianti K. D. P \& Sedana G Y H, 2019. "Pelatihan Pemasaran Dengan Menggunakan Media Sosial Pada Usaha Penjahit Kebaya Devi di Kerambitan Tabanan" WIDYABHAKTI JURNAL ILMIAH POPULER V1(3): 96-101

Wong J. 2010. 'Internet Marketing For Beginners', Jakarta: PT. Elex Media Komputindo.

As'ad, H. Abu-Rumman. 2014. The Impact 
of Social Media marketing on Brand Equity: An Empirical Stuqy on Mobile Service Providers in Jordan. Journal Society of Interdiciplinary Business Research Vol. 3 No. 1 ISSN: 23041013;2304-1269

Puntoadi, Danis. 2011. Meningkatkan Penjualan Melalui Media Sosial. Jakarta: Gramedia Pustaka Utama

Nisrina. 2015. Bisnis Online: Manfaat Media Sosial dalam Meraup Uang. Yogyakarta: Kobis

Anwari, E., Meilani, E. \& Prasetyowati, O., 2018. Perancangan Grafis Kemasan Makanan Burayot Sebagai Oleh-Oleh Khas Garut. DeKaVe, 10(2), pp.12-24. 